\title{
PENGARUH TERAPI STORYTELLING TERHADAP TINGKAT KECEMASAN DAN PROBLEM FOCUSED COPING MAHASISWA YANG SEDANG SKRIPSI
}

\author{
Agus Poerwanto \\ Fety Khosianah \\ Fakultas Psikologi Universitas Muhammadiyah Surabaya \\ aguspoerwanto@yahoo.com \\ fety_kh@yahoo.com
}

\begin{abstract}
Abstrak
Penelitian ini bertujuan untuk mengetahui apakah ada pengaruh terapi Storytelling terhadap kecemasan dan problem focused coping mahasiswa yang sedang skripsi. Penelitian ini merupakan penelitian kuantitatif menggunakan desain eksperimen (experimental research). Subyek dalam penelitian ini adalah mahasiswa tingkat akhir Fakultas Psikologi Universitas Muhammadiyah Surabaya. Hasil perhitungan uji t (paired $t$-test) tingkat kecemasan diperoleh hasil $\mathrm{t}$ hitung sebesar $=-0,61$. Hasil perhitungan uji $\mathrm{t}$ (paired $t$-test) tingkat problem focused coping diperoleh hasil t hitung sebesar $=-0,283$, taraf signifikansi 0,05. Dari hasil uji t tersebut, dapat disimpulkan bahwa tidak ada perbedaan antara tingkat kecemasan dan problem focused coping mahasiswa yang sedang skripsi antara sebelum dan sesudah diberikan terapi storytelling.
\end{abstract}

Kata kunci : storytelling, kecemasan, problem focused coping

\section{PENDAHULUAN}

Setiap mahasiswa yang menempuh studi pasti menantikan saat-saat bahagia yaitu bisa lulus tepat waktu. Semua orang tua pastilah juga menginginkan anaknya bisa segera mewujudkan cita-citanya selepas lulus kuliah. Orang tua sudah berupaya dan bekerja keras membiayai pendidikan anaknya sehingga orangtua pun punya harapan yang besar agar anaknya bisa lulus tepat waktu.

Tidak sedikit mahasiswa yang membutuhkan waktu lama dalam menyelesaikan skripsinya. Berbagai macam alasan dan kendala mempengaruhi proses penyelesaian skripsi. Hambatanhambatan yang terjadi dalam proses penyelesaian skripsi sering membuat mahasiswa merasa tertekan, tidak sedikit yang mengalami kecemasan hingga stres. Bila mahasiswa berada dalam situasi yang tidak menentu dan tidak pasti terhadap kemampuannya untuk menyelesaikan skripsi maka akan muncul kecemasan, diantaranya perasaan tertekan, kekhawatiran dan ketakutan akan kegagalan menyelesaikan skripsi tepat waktu.

Ada banyak faktor dalam kehidupan sehari-hari yang dapat berkontribusi pada peningkatan stres mahasiswa. Misalnya, meningkatnya beban kerja akademik, berada jauh dari rumah, menemukan dan mempertahankan pekerjaan, menjaga hubungan pribadi, kewajiban finansial, menyesuaikan diri dengan lingkungan baru (Negga, Applewhite, Livingston, 2007), seiring dengan persaingan kelas, meningkatnya kompleksitas materi pembelajaran, dan penyesuaian sosial. Beberapa hambatan tersebut banyak dihadapi mahasiswa setiap hari sehingga tidak mengherankan bahwa penelitian terbaru yang dilakukan oleh Mahmoud, dkk (2012) menunjukkan bahwa mahasiswa mengalami kenaikan tingkat depresi, kecemasan dan stres. 
Kecemasan yang terus menerus dan tidak mampu dikendalikan oleh individu semakin lama akan semakin menekan psikis atau emosi sehingga kemudian menimbulkan stress. Menurut Slamet, dkk (2003), stres adalah suatu keadaan dimana beban yang dirasakan seseorang tidak sepadan dengan kemampuan untuk mengatasi beban itu.

Beban studi yang tidak kunjung selesai, dalam hal ini proses penyelesaian skripsi, merupakan sebuah stresor yang membawa permasalahan tersendiri bagi kehidupan mahasiswa. Permasalahan tersebut memerlukan suatu pemecahan agar mahasiswa dapat menyesuaikan diri dan dapat menghadapi apa yang terjadi pada dirinya. Pemecahan tersebut disebut dengan koping stres. Koping stres merupakan respons individu dengan cara tertentu terhadap jenis stres yang dialaminya (Dewi, 2012).

Menurut Nevid, dkk (2005), ada dua jenis koping stres. Koping yang yang berfokus pada masalah (problem-focused coping) Koping yang berfokus pada emosi (emotion-focused coping)

Salah satu jenis terapi yang dikembangkan untuk menurunkan kecemasan seseorang adalah terapi storytelling. Terapi storytelling membuat klien tidak cemas karena adanya peran dari hipotalamus (Suyatmi, 2014).

\section{Rumusan Masalah}

Rumusan masalah dalam penelitian ini adalah "apakah terdapat pengaruh terapi storytelling terhadap tingkat kecemasan dan problemfocused coping mahasiswa yang sedang skripsi?"

\section{Tujuan Penelitian}

Penelitian ini secara khusus bertujuan untuk menguji pengaruh terapi storytelling terhadap tingkat kecemasan dan problem focused coping mahasiswa yang sedang skripsi.

\section{Manfaat Penelitian}

Penelitian ini diharapkan bisa memberikan manfaat bagi pihak institusi pendidikan khususnya fakultas atau program studi yaitu bisa memberikan masukan kepada dosen untuk memberikan layanan konseling kepada mahasiswa yang mengalami kecemasan dalam menyelesaikan skripsi.

\section{TINJAUAN PUSTAKA}

\section{Terapi Storytelling}

Storytelling merupakan bentuk akrab dari komunikasi, cerita faktual yang mendidik, menyentuh, dan merangsang seseorang untuk bertindak. Storytelling adalah media yang efisien untuk membuat orang memahami, mengingat, dan menerima informasi baru (Grissinger, 2014).

Dewan Nasional Guru Bahasa Inggris (2005) mendefinisikan storytelling sebagai kegiatan bercerita dengan lebih dari satu pendengar, dan tidak hanya berbentuk membaca cerita dari memori atau teks, tetapi lebih jauh dalam bentuk penciptaan citra mental dari unsur-unsur cerita melalui suara dan gerakan. Dan, melalui proses bercerita, pemberi cerita dan penontonnya memberikan perhatian penuh dan terlibat dalam pengalaman belajar (dalam Eck, Jill, 2006)

\section{Manfaat Storytelling}

Grissinger, M (2014) mengemukakan mengenai The Power of the Story diantaranya yaitu :

1. Cerita mampu menarik perhatian. Cerita mengekspos dilema dengan cara yang sangat meningkatkan perhatian seseorang untuk masalah tersebut.

2. Cerita mempromosikan berpikir kritis. Cerita menimbulkan pertanyaan penting, sering menantang asumsi yang sudah ada, dan membuka seseorang untuk berpikir dengan cara-cara baru berpikir tentang suatu masalah.

3. Cerita mengesankan.

Orang lebih cenderung untuk mengingat informasi bersama melalui 
cerita dari informasi yang disajikan melalui data.

4. Cerita menciptakan empati.

Penelitian menunjukkan bahwa berbagi cerita faktual dapat meningkatkan penyembuhan dengan memberdayakan korban untuk menyuarakan pengalaman mereka, yang mengarah ke penilaian yang lebih baik dari situasi dan meningkatkan pemahaman dan empati di kalangan pembaca dan pendengar.

5. Cerita mengilhami perubahan.

Penelitian menunjukkan efek persuasif cerita, terutama bila dibandingkan dengan presentasi abstrak data. Penelitian lebih lanjut menunjukkan kemampuan cerita untuk menginspirasi, memotivasi, dan membuat perbedaan dalam kehidupan masyarakat.

\section{Kecemasan}

Menurut Lazarus (dalam Pradono dan Purnamasari, 2010), kecemasan merupakan pengalaman subyektif yang tidak menyenangkan mengenai kekhawatiran atau ketegangan berupa perasaan cemas, tegang, dan emosi yang dialami oleh seseorang. Kecemasan adalah suatu keadaan tertentu (state anxiety), yaitu menghadapi situasi yang tidak pasti dan tidak menentu terhadap kemampuannya dalam menghadapi obyek tersebut. Hal tersebut berupa emosi yang kurang menyenangkan yang dialami oleh individu dan bukan kecemasan sebagai sifat yang melekat pada kepribadian.

\section{Macam-macam Kecemasan}

Spielberger (dalam Gunarsa, 2008) membedakan kecemasan menjadi dua, antara lain yaitu :

\section{1) Trait Anxiety}

Lazarus berpendapat bahwa trait anxiety adalah disposisi untuk menjadi cemas dalam menghadapi berbagai macam situasi. Hal ini merupakan ciri atau sifat yang cukup stabil yang mengarahkan seseorang atau menginterpretasikan suatu keadaan menetap pada individu, bersifat bawaan dan berhubungan dengan kepribadian yang demikian (dalam Ghufron dan Risnawita, 2014).

2) State Anxiety

Menurut Lazarus, state anxiety adalah reaksi emosi sementara yang timbul pada situasi tertentu yang dirasakan sebagai ancaman, misalnya mengikuti tes, menjalani operasi, atau lainnya. Keadaan ini ditentukan oleh perasaan tegang yang subjektif (dalam Ghufron dan Risnawita, 2014).

\section{Penyebab Kecemasan}

Deffenbacher dan Hazaleus (dalam Ghufron dan Risnawita, 2014) menyebutkan adanya sumber penyebab kecemasan diantaranya yaitu :

1) Kekhawatiran (worry) Merupakan pikiran negatif tentang dirinya sendiri, seperti perasaan negatif bahwa ia lebih jelek dibandingkan teman-temannya.

2) Emosionalitas (emotionality) Merupakan reaksi diri terhadap rangsangan saraf otonomi, seperti jantung berdebar-debar, berkeringat dingin dan ketegangan otot.

3) Gangguan dan hambatan dalam menyelesaian tugas (task generated interference), yaitu kecenderungan yang dialami seseorang yang selalu tertekan karena pemikiran yang rasional terhadap tugas.

\section{Tingkatan Kecemasan}

Menurut Stuart (dalam Riyadi dan Purwanto, 2009) kecemasan dibagi menjadi empat tingkatan, yaitu :

1) Kecemasan Ringan

Berhubungan dengan ketegangan dalam kehidupan sehari-hari, kecemasan dalam tingkat ringan ini menyebabkan seseorang menjadi 
waspada dan meningkatkan lahan presepsinya.

2) Kecemasan Sedang

Memungkinkan seseorang utuk memusatkan pada hal yang penting dan mengesampingkan yang lain sehingga seseorang mengalami tidakperhatian yang selektif namun dapat melakukan sesuatu yang lebih banyak jika diberi arahan.

3) Kecemasan Berat

Kecemasan dalam tingkatan berat sangat mengurangi lahan persepsi seseorang. Individu cenderung untuk berfokus pada sesuatu yang terinci dan spesifik serta tidak dapat berpikir tentang hal yang lain.

4) Tingkat panik

Pada tingkatan ini, kecemasan berhubungan dengan ketakutan dan teror. Karena mengalami kehilangan kendali, individu yang mengalami panik tidak mampu melakukan sesuatu walaupun dengan pengarahan.

\section{Indikator Kecemasan}

Riyadi dan Purwanto (2009) menjelaskan indikator-indikator kecemasan diantaranya adalah respons perilaku, kognitif dan afektif yang dijabarkan sebagai berikut :

1) Perilaku

Respon dari dimensi perilaku ini diantaranya adalah gelisah, ketegangan fisik, reaksi terkejut, bicara cepat, kurang koordinasi, cenderungmengalami cedera, menarik diri dari hubungan interpersonal, inhibisi, melarikan diri dari masalah, menghindar, hiperventilasi, sangat waspada.

2) Kognitif

Respon dari dimensi kognitif dari kecemasan diantaranya adalah perhatian terganggu, konsetrasi buruk, pelupa, salah dalam memberikan penilaian, preokupasi, hambatan berpikir, lapang persepsi menurun, bingung, sangat waspada, kesadaran diri, kehilangan obyektivitas, takut kehilangan kendali, takut pada gambaran visual, takut cedera atau kematian, mimpi buruk.

3) Afektif

Respon dari dimensi afektif kecemasan adalah mudah terganggu, tidak sabar, tegang, gugup, ketakutan, waspada, rasa bersalah, mati rasa, malu, kecemasan, kekhawatiran.

\section{Problem Focused Coping}

Lazarus (1993), coping didefinisikan sebagai upaya kognitif dan perilaku yang sedang berlangsung untuk mengelola tuntutan eksternal dan/ atau internal spesifik yang dinilai berat atau melebihi sumber daya individu.

Sarafino (1994) menjelaskan bahwa coping adalah proses dimana seseorang mencoba untuk mengatur perbedaan yang dirasakan antara tuntutan dan sumber yang dinilai dari situasi stres. Tuntutan yang berat berasal dari luar maupun dari dalam individu yang mengalami stres.

\section{Bentuk Strategi Coping}

Menurut Folkman, dkk (dalam Nevid dkk, 2005), strategi koping yang diakui secara luas terbagi menjadi dua strategi utama, yaitu koping yang berfokus pada masalah (problem-focused coping) dan koping yang berfokus pada emosi (emotion-focused coping)

a. Koping yang berfokus pada masalah (problem-focused coping)

Problem-focused coping adalah suatu strategi yang diarahkan pada masalah yang dialami seseorang serta upaya untuk memecahkan masalah tersebut. Pada koping ini orang menilai stresor yang mereka hadapi dan melakukan sesuatu untuk mengubah stresor atau memodifikasi reaksi mereka untuk meringankan efek dari stresor tersebut. 
b. Koping yang berfokus pada emosi (emotion-focused coping)

Emotion-focused coping adalah suatu gaya koping dengan berusaha meminimalisasi respons emosional, bukan dengan mengatasi stresor langsung. Pada koping yang berfokus pada emosi, individu berusaha segera mengurangi dampak stresor, dengan menyangkal adanya stresor atau menarik diri dari situasi.

\section{Indikator Koping Yang Berfokus Pada Masalah (Problem-Focused Coping)}

Indikator yang menunjukkan strategi yang berorientasi pada problemfocused coping (dalam Nevid dkk, 2005)yaitu:

1) Konfrontasi

Menurut Folkman, dkk, (1986) Konfrontasi mengacu pada upaya langsung untuk mengubah situasi. Individu biasanya ketika menggunakankonfrontasi

cenderung bermusuhan dan mengekspresikan kemarahannya dengan orang yang berhubungan dengan masalah yang sedang dihadapi.

2) Mencari dukungan sosial Mencari dukungan sosial mengacu pada bagaimana individu memperoleh pengetahuan tentang situasi stres, yang kemudian dapat digunakan dalam strategiproblemfocused coping. Menurut Lazarus, dkk (1986), mencari dukungan sosial menjelaskan upaya untuk mencari dukungan informasi, dukungan nyata, dan dukungan emosional.

3) Merencanakan pemecahan masalah Perencanaan mengacu tentang bagaimana individu mengatasi stressor. Perencanaan melibatkan strategi untuk mengambil tindakan, berpikir tentang langkah apa yang harus diambil dan cara terbaik untuk menangani masalah yang dihadapi individu (Carver, dkk, 1989).

\section{METODE PENELITIAN}

Penelitian ini merupakan penelitian kuantitatif menggunakan desain eksperimen (experimental research) yaitu penyelidikan dengan cara mengenakan faktor penyebabnya (treatment/perlakuan) kepada kelompok eksperimental, kemudian dikaji akibat yang terjadi untuk meyakinkan bahwa yang terjadi itu benar-benar sebagai akibat dari perlakuan.

Subyek dalam penelitian ini adalah mahasiswaFakultas Psikologi Universitas Muhammadiyah Surabaya dengan sampel yang diambil secara purposive(Purposive Sampling), dengan kriteria : mahasiswa tingkat akhir yang sedang mengerjakan skripsi dan bersedia menjadi subyek penelitian..

Penelitian ini menggunakan metode quasi experiment dengan model One Group Pretest Posttest Design yaitu memberikan perlakuan (treatment) kepada satu kelompok eksperimen sehingga bisa diukur perbedaan antara sehingga bisa diukur perbedaan antara sebelum dan sesudah perlakuan tersebut.

Prosedur penelitian ini adalah sebagai berikut :

1) Peneliti memberikan skala kecemasan dan skala problem focused coping kepada subyek dalam rangka untuk mengukur sejauhmana tingkat kecemasan dan problem focused coping sebelum diberikan perlakuan (terapi storytelling).

2) Peneliti memberikan perlakuan atau intervensi kepada subyek yakni berupa terapi storytelling dalam jangka waktu 2 (dua) jam.

3) Peneliti melakukan posttest yaitu memberikan instrumen (alat ukur) yang sama untuk mengukur kembali tingkat kecemasan dan problem focused coping-nya setelah perlakuan (treatment) diberikan. 
4) Peneliti kemudian membandingkan hasil pretest dan posttest untuk mengetahui perbedaan yang terdapat diantara keduanya. Jadi, apabila terdapat perbdeaan maka hal tersebut akibat dari adanya perlakuan yaitu terapi storytelling.

5) Dilakukan uji statistik yakni paired sampel t-test untuk mengetahui apakah dari perbedaan yang ditemukan bersifat signifikan atau tidak.

tersebut.

belum dan sesudah perlakuan

Data yang telah dikumpulkan, dianalisa secara statistik dengan menggunakan uji Paired Sample T-test. Analisis Paired-Samples T-test merupakan prosedur yang digunakan untuk membandingkan rata-rata dua variabel dalam satu grup.

\section{HASIL PENELITIAN}

Tingkat kecemasan subyek sebelum perlakuan berada pada tingkat kecemasan sedang sebanyak 7 orang $(43,75 \%)$ dan tingkat kecemasan berat sebanyak 9 orang $(56,25 \%)$, sedangkan sesudah perlakuan berada pada tingkat kecemasan sedang sebanyak 5 orang $(31,25 \%)$ dan tingkat kecemasan berat sebanyak 11 orang $(68,75 \%)$.

Tingkat Problem Focused Coping subyek sebelum perlakuan berada pada tingkat rendah sebanyak 14 orang $(87,5 \%)$ dan tingkat tinggi sebanyak 2 orang $(12,5 \%)$, sesudah perlakuan tingkat rendah sebanyak 11 orang $(68,57 \%)$ dan tingkat tinggi 5 orang $(31,25 \%)$.

Hasil perhitungan uji t-test (paired t-test) tingkat kecemasan diperoleh hasil $\mathrm{t}$ hitung sebesar $=-0,61$, taraf signifikansi 0,05.Kesimpulannya tidak ada perbedaan antara tingkat kecemasanmahasiswa yang sedang skripsi sebelum dan sesudah diberikan stortytelling.

Hasil perhitungan uji t-test (paired t-test) tingkat problem focused coping diperoleh hasil $\mathrm{t}$ hitung sebesar $=-0,283$, taraf signifikansi 0,05.Kesimpulannya tidak ada perbedaan antara tingkat problem focused coping mahasiswa yang sedang skripsi sebelum dan sesudah diberikan stortytelling.

\section{PEMBAHASAN}

Masing-masing individu mempunyai cara penyesuaiannya dalam menghadapi beragam stres. Mahasiswa akan bereaksi secara berbeda terhadap stres, tergantung berbagai faktor psikologis seperti bagaimana individu memaknai peristiwa yang menimbulkan stres tersebut. Seorang mahasiswa yangmenggunakan strategi problem-focused coping cenderung memiliki keyakinan dalam dirinya akan dapat mengubah situasi, sehingga akan berorientasi mencari dan menghadapi pokok permasalahan yang sedang dihadapi.

Pencegahan yang baik untuk mengurangi kecemasan dan meningkatkan kemampuan strategi problem-focused copingmahasiswa yang sedang skripsi adalah dengan membangkitkan mahasiswa dengan memberikannya motivasi melalui proses storytelling. Diharapkan dengan pemberian storytelling dapat terjadi proses belajar mengambil hikmah dari isi cerita.

Hasil penelitian yang
menyimpulkan bahwa tidak ada pengaruh yang signifikan terapi storytelling terhadap tingkat kecemasan dan problem focusedcoping mahasiswa yang sedang skripsi di Fakultas Psikologi Universitas Muhammadiyah Surabaya sejalan dengan penelitian Arwiyanti (2012) yang menemukan bahwa pemberian storytelling tidak berpengaruh secara signifikan terhadap tingkat kecemasan anak ( $\mathrm{p}$ value $>0,05)$. Hasil penelitian ini juga sejalan dengan hasil penelitian Tarwiyati (2013) yang membuktikan bahwa tidak ada hubungan yang signifikan antara tingkat problem-focused coping dengan tingkat stres.

$$
\begin{aligned}
& \text { Secara teoritis, storytelling } \\
& \text { merupakan terapi yang sifatnya } \\
& \text { menghipnotis dan memberi sugesti kepada } \\
& \text { individu. Dengan storytelling membuat } \\
& \text { individu rileks dan terlarut dalam cerita } \\
& \text { yang diberikan sehingga dapat menurunkan }
\end{aligned}
$$


tingkat kecemasan. Dengan menurunnya tingkat kecemasan maka akan mendorong meningkatnya kemampuan coping yang berfokus pada masalah (problem focused coping).

Faktor-faktor yang mempengaruhi efektivitas dari sebuah terapi sangat bervariasi dan tergantung kepada banyak aspek. Interaksi antara berbagai aspek tersebut sangatlah kompleks dan faktor kunci dalam efektivitas penurunan kecemasan maupun peningkatan strategi coping adalah kualitas serta kuantitas dari storytelling yang diberikan.

\section{KESIMPULAN}

Melalui uji perbedaan ditemukan bahwa tidak ada perbedaan yang signifikan antara tingkat kecemasan mahasiswa yang sedang skripsi. Hasil tersebut ditunjukkan dengan $\mathrm{t}=-0,61$, taraf signifikansi 0,05 . Dengan kata lain, tidak ada pengaruh terapi storytelling terhadap tingkat kecemasan pada mahasiswa yang sedang skripsi.

Hasil perhitungan uji t-test (paired $t$ test) tingkat problem focused coping didapatkan hasil nilai $\mathrm{t}=-0,28$, taraf signifikansi 0,05 , yang artinya disimpulkan bahwa tidak ada perbedaan tingkat problem focused coping sebelum dan sesudah diberikan terapi storytelling.

Dengan demikian dapat disimpulkan bahwa tidak ada pengaruh yang signifikan terapi storytelling terhadap tingkat kecemasan dan problem focused coping mahasiswa yang sedang skripsi di Fakultas Psikologi Universitas Muhammadiyah Surabaya.

\section{DAFTAR PUSTAKA}

Arwiyanti, Wahyu Tri. 2012. Pengaruh Storytelling Terhadap Tingkat Kecemasan pada Anak Usia Sekolah DI Rumah Sakit Islam Sultan Agung Semarang. Fakultas Ilmu Keperawatan UNISSULA : Tesis.
Durand, M., Barlow, D.H. 2006. Intisari Psikologi Abnormal. Jogyakarta: Pustaka Belajar.

Dewi, K.S. 2012. Buku Ajar Kesehatan Mental. Semarang: UPT UNDIP Press.

Eck, Jill. 2006. An Analysis of The Effectiveness of Storytelling With Adult Learner In Supervisoty Management.

https://www.thelibrarybook.net/pdfan-analysis-of-the-effectiveness-ofstorytelling-with-adult-learners-insupervisory-management-jilleck.html.Diunduh tanggal 10 Maret 2016.

Feist dan Feist. 2009. Teori Kepribadian. Jakarta : Salemba Humanika.

Forman, Jeffrey. 2007. Managing Physical Stress With Therapeutic Massage. United States of America: Delmar Cengage.http://milady.cengage.com/ imgs/1418014893_ManagingPhysica 1Stress.pdf. Diunduh tanggal $20 \mathrm{Mei}$ 2016

Ghufron, N. M., Risnawita, S.R. 2014. Teori-teori Psikologi. Jogjakarta : ArRuzz Media.

Gunarsa, Singgih D. 2008. Psikologi Olahraga Prestasi. Jakarta : PT. BPK Gunung Mulia.

Gunarti, Winda. 2010. Metode Pengembangan Perilaku dan Kemampuan Dasar Anak Usia Dini. Jakarta : Universitas Terbuka.

Grissinger, Matthew. 2014. Telling True Stories Is an ISMP Hallmark. A Peer Review Journal For Managed Care and Hospital Formulary Management. http://www.ncbi.nlm.nih.gov/pmc/ar ticles/PMC4189689/\#b1- 
ptj4910658. Diunduh tanggal 20 Mei 2016

Hasan, Iqbal. 2010. Pokok-Pokok Materi Statistik 2 (Statistik Inferensial). Jakarta: Bumi Aksara

Husdarta, H.J.S. 2010. Psikologi Olahraga. Bandung : Alfabeta.

Iswara, Amalia D. 2014. Pengaruh metode bercerita dalam menurunkan nyeri pada anak prasekolah yang terpasang infus di Rumah Sakit Islam Surabaya. www.stikeshangtuah-

sby.ac.id/v1/download.php?f=MAN O\%20SKRIP.pdf. Diunduh tanggal 20 Mei 2016.

Kartono, K. 2012. Patologi Sosial 3. Gangguan-Gangguan Kejiwaan, Cetakan Ketujuh. Fajar Interpratama Mandiri Offset.

Lazarus, R.S. 1993. Coping Theory and Research: Past, Present, and Future. Psychosomatic Medicine 55:234247.

Lumbansiantar, Rupdi. 2012. Pengaruh Storytelling terhadap Tingkat Kecemasan Akibat Hospitalisasi Pada Anak Usia Pra Sekolah Dini. https://ayurvedamedistra.files.wordp ress.com/2015/08/pengarus-storytelling-terhadap-tingkat-kecemasanakibat-hospitalisasi-pada-anak-usiasekolah.pdf. Diunduh tanggal 15 Maret 2016.

Mahmoud, JS.., Staten, R., Hall, L.A., Lennie, T.A. 2012. The Relationship among Young Adult College Student's Depression, Anxiety, Stress, Demographics, Life Satisfaction, and Coping Styles. Issues Mental Health Nursing. Vol. 33. No. 3. Hal. 149-156. https://www.ncbi.nlm.nih.gov/pubm ed/22364426. Diunduh tanggal 12 Agustus 2017.

Negga, F., Applewhite, S., Livingston, I. 2007. African American College Students and Stress : School Racial Composition, Self Esteem and Social Support. College Student Journal, Vol. 41, no. 4, hal. 823-830. Desember 20017. https://eric.ed.gov/?id=EJ816806. Diunduh tanggal 12 Agustus 2017.

Nisrina, G.E. 2013. Perbedaan strategi coping stres pada mahasiswa organisasi dan non organisasi di Universitas Islam Negeri Maulanan Malik Ibrahim Malang. http://etheses.uinmalang.ac.id/3649/1/12410048.pdf. diunduh tanggal 1 September 2017.

Nevid, Jeffrey S., Rathus, Spencer A., Greene, Beverly. 2005. Psikologi Abnormal Edisi Kelima Jilid 1 (Terjemahan). Jakarta: Erlangga.

Pradono, G. S, dan Purnamasari, S. E. 2010. Hubungan Antara Penyesuaian Diri Dengan Kecemasan Dalam Menghadapi Masa Pensiun Pada Pegawai Negeri Sipil di Propinsi DIY.http://fpsi.mercubuanayogya.ac.id/wpcontent/uploads/2012/06/Agustus 20 10_Santi-Esterlita-P.pdf. Diunduh tanggal 15 Maret 2016.

Riyadi, S., Purwanto, T. 2009. Asuhan Keperawatan Jiwa. Yogyakarta : Graha Ilmu.

Ryan, K. 2013. How problem focused and emotion focused coping affects college students'perceived stress and life satisfaction.http://esource.dbs.ie/bitst ream/handle/10788/1622/ba_ryan_k 2013.pdf?sequence $=1$. Diunduh tanggal 15 Maret 2016. 
Santrock, J.W. 2007. Life Span Development. Jakarta: Penerbit Erlangga.

Sarafino, E.P. (1994). Health Psychology: Biopsychosocial Interactions. United States of America: John Wiley \& Sons, Inc.

Slamet, S. dan Markam, S. 2003. Pengantar Psikologi Klinis. Jakarta: UI-Press.

Suyatmi, S., Nurul, M., Azizah, K. 2014. Pengaruh Terapi Storytelling Terhadap Tingkat Kecemasan Klien Pra-Operasi Apendiktomi. Pascasarjana Universitas Muhammadiyah Yogyakarta. Tesis.

Tarwiyati, Heruma. 2013. Hubungan Antara Tingkat Problem-Focused Coping Dengan Tingkat Stres Pada Mahasiswa Yang Sedang Menyusun Sripsi Di Universitas Muhammadiyah Gresik. Jurnal Psikosains. Volume 6. Nomor 1. Agustus 2013

The Healing Through Remembering Storytelling sub group. 2005. Conference Dunadry Hotel, Dunadry, $29 \quad$ November 2005. http://www.healingthroughremembe ring.org. Diunduh tanggal 10 Maret 2016.

Yenjelli, Lusi. 2007. Strategi Coping pada Single Motheryang Bercerai. http://www.gunadarma.ac.id/library/ articles/graduate/psychology/2007/A rtikel_10502145.pdf. Diunduh tanggal 10 Maret 2016.

Yuniartini, P.E., Widastra, M., Utami, K.C. 2013. Pengaruh Terapi Bercerita Terhadap Kualitas Tidur Anak Usia Prasekolah Yang Menjalani Hospitalisasi Di Ruangan Perawatan
Anak RSUP SANGLAH DENPASAR.

http://download.portalgaruda.org/arti cle.php?article $=80892 \&$ val $=956 \mathrm{Diu}$ nduh tanggal 20 Mei 2016. 